\title{
Serum Resistin in Lean Rheumatoid Arthritis Patients: Does it correlate with disease activity and radiological joint damage?
}

\author{
Abeer Shahba $^{1}$, Noha E. Esheba ${ }^{1}$, Fawkia Mahgoub ${ }^{2}$, Naglaa Ghoname ${ }^{2}$ \\ Departments of Internal Medicine ${ }^{1}$, Microbiology ${ }^{2}$, Tanta University; Egypt
}

\begin{abstract}
Objective: Determination of whether serum resistin in lean rheumatoid arthritis patients correlates with disease activity and radiological joint damage or not. Subjects and Methods: 75 subjects were included; 25 patients diagnosed with active rheumatoid arthritis (RA), 25 patients with inactive RA, and 25 healthy individuals served as control. All were subjected to history taking, clinical examination, routine laboratory investigations and determination of serum resistin level. Plain X-ray of both hands and feet for RA patients and assessed according to Larsen score. Results: There was a significant increase in serum resistin level in active RA when compared to inactive RA and controls. Resistin also showed a significant positive correlation with DAS 28 score, ESR, CRP, RF, anti CCP, TC, TG, LDL, but the correlation with Larsen score was not significant. Conclusion: There is association between serum resistin level and disease activity, suggesting that it may be useful in evaluating RA disease activity. [Egypt J Rheumatology \& Clinical Immunology, 2015; 3(2): 121-126]
\end{abstract}

Key Words: Resistin, rheumatoid arthritis.

\section{INTRODUCTION}

Rheumatoid arthritis (RA) is a systemic autoimmune inflammatory disorder of unknown etiology that primarily affects the synovial lining of the diarthrodial joints. It is characterized by symmetric, erosive synovitis and in some cases extraarticular involvement ${ }^{1}$.

Resistin was originally discovered as a molecule that induced insulin resistance and caused hyperglycemia without affecting peripheral insulin sensitivity ${ }^{2}$.

However, data in humans are controversial. In contrast to mice, resistin in humans is expressed in lower levels in adipocytes but at relatively higher levels in circulating blood monocytes ${ }^{3}$.

There was evidence that resistin has proinflammatory properties, in abundant of inflammatory diseases e.g., RA and Crohn's disease; and is also associated with inflammatory markers in several different populations ${ }^{4}$.

Resistin has the potency of inducing production of interleukin -6 and tumor necrosis factor-alpha ${ }^{5-6}$. Also Resistin induces inflammatory cytokines and causes arthritis when injected into the joints of mice $^{6}$.

The aim of the present study was the assessment of serum resistin in lean rheumatoid arthritis patients and whether it correlates with disease activity and radiological joint damage or not.

\section{SUBJECTS AND METHODS}

Fifty patients ( 3 males and 47 females) fulfilling the American College of Rheumatology 1987 revised criteria for classifying $\mathrm{RA}^{7}$, were recruited at the wards and outpatient clinic of Internal Medicine department of Tanta University Hospital during a period of one year from $1 / 6 / 2013$ to $1 / 6 / 2014$. Twenty five healthy subjects of matching age and sex were also included as a control group ( 2 males and 23 females). RA patients were divided into 2 groups.

- $\quad$ Group (I): 25 active RA patients (1 male and 24 females).

- Group (II): 25 patients with inactive RA (2 males and 23 females).

- Group (III): 25 apparently healthy individuals served as control group ( 2 males and 23 females).

Inclusion criteria:

Patients aged $>18$ years with RA.

Exclusion criteria:

- Patients with any other autoimmune or inflammatory diseases.

- $\quad$ Body mass index (BMI) $\geq 25 \mathrm{~kg} / \mathrm{m}^{2}$.

- Patients with diabetes mellitus (FBG $\geq 126)$.

The disease activity of patients with rheumatoid arthritis was assessed according to the 28 joint count Disease Activity Score (DAS28) instrument ${ }^{8}$, using the number of swollen and tender joints, erythrocyte sedimentation rate (ESR) and patient's global visual 
analogue scale (VAS). The rheumatoid Disease Activity Score 28 (DAS28) was determined from scores as follows: Remission: DAS $28<2.6$, Low disease activity: DAS $28>2.6<3.2$, Moderate disease activity: DAS $28>$ 3.2 and $<5.1$, High disease activity: DAS $28>5.1$. DAS $28=[0.56 \times \sqrt{ }($ tender 28$)+0.28 \times \sqrt{ }($ swollen 28$)+0.70$ $\times \operatorname{Ln}(\mathrm{ESR})] 1.08+0.16(14)$.

All patients signed an informed consent and the study was approved by the local ethics committee. The participants were subjected to the following:

Complete history taking. Routine laboratory investigations in the form of: Complete blood count $(\mathrm{CBC})$, rheumatoid factor (RF) using quantitive immunonephelometry, anti-cyclic citrullinated antibody (Anti CCP) using microparticle enzyme immunoassay (MEIA), C reactive protein (CRP) using latex method, erythrocytes sedimentation rate (ESR) by Westergren method, lipid profile: total cholesterol, triglyceride and low density lipoprotein (TC, TG, LDH), and fasting blood glucose. Plain X ray of both hands and feet for RA patients to determined the degree of radiographic joint damage using the Larsen score ${ }^{9-10}$.

\section{Specific investigation:}

Serum resistin level was measured using the enzyme-linked immunosorbent assay method ELISA (R\&D system Poston Biochem, 840 Memorial Dravee, Cambridge). The sensitivity of the assay was 0.055 $\mathrm{ng} / \mathrm{ml}$. The intra-assay coefficient of variation was $4.7 \%$, while the inter-assay coefficient of variation was $8.4 \%$.

\section{Statistical Analysis:}

Comparisons between two groups were performed using a two-tailed unpaired Student t test. Multiple groups were compared using a two-way
ANOVA. Data were presented as mean \pm standard deviation and range. Comparisons were made by using the nonparametric Mann-Whitney test. In case of more than two samples, the nonparametric KruskalWallis test was performed. Correlations were assessed by using the Pearson correlation test. $\mathrm{P}$ value less than 0.05 was considered statistically significant. All analyses were performed using SPSS statistical software (SPSS V.16, Inc., Chicago, IL).

\section{RESULTS}

In this work, fifty patients with RA were included. Twenty five of them with active disease (24 females, 1 male), and 25 patients with inactive RA ( 23 females, 2 males). Twenty five healthy individuals of matching age and sex served as control group (23 females, 2 males). Table (1) shows age, sex, duration of diagnosis, DAS 28, Larsen score and laboratory abnormalities in the studied groups. Table (2) shows the treatments received by RA patients.

Serum resistin was significantly higher in patients with active RA than controls $(\mathrm{P}=0.001)$, also in patients with inactive $\mathrm{RA}$, it was significantly higher than controls $(\mathrm{P}=0.002)$. There was a significant increase in its level in patients with active RA when compared to patients with inactive $\mathrm{RA}(\mathrm{P}=$ 0.001), Table (3).

Also serum resistin in this work showed a significant positive correlation with all of the following: DAS 28 score, ESR, CRP, RF, anti CCP, TC, TG, LDL with $(\mathrm{P}<0.001$ for all), but the positive correlation was insignificant with Larsen score, BMI, and FBG, as shown in Table (4).

Table 1. Clinical characteristics of the studied groups.

\begin{tabular}{|c|c|c|c|c|c|}
\hline & & $\begin{array}{c}\text { Group I } \\
\text { Active RA (25) }\end{array}$ & $\begin{array}{c}\text { Group II } \\
\text { Inactive RA (25) }\end{array}$ & $\begin{array}{c}\text { Group III } \\
\text { NC group }(25) \\
\end{array}$ & P-value \\
\hline Sex & (female/male) & $24 / 1$ & $23 / 2$ & $23 / 2$ & 0.168 \\
\hline Age (years) & $\begin{array}{l}\text { Range } \\
(\text { Mean } \pm S D)\end{array}$ & $\begin{array}{c}25-60 \\
(42.32 \pm 9.1) \\
\end{array}$ & $\begin{array}{c}23-59 \\
(37.8 \pm 8.74) \\
\end{array}$ & $\begin{array}{c}23-58 \\
(39.72 \pm 8.76) \\
\end{array}$ & 0.2 \\
\hline $\begin{array}{l}\text { Duration of } \\
\text { disease (years) }\end{array}$ & $\begin{array}{l}\text { Range } \\
(\text { Mean } \pm S D)\end{array}$ & $\begin{array}{c}0.5-10 \\
(6.66 \pm 3.05) \\
\end{array}$ & $\begin{array}{c}2-15 \\
(6.56 \pm 5.08) \\
\end{array}$ & NA & 0.93 \\
\hline DAS 28 score & $\begin{array}{l}\text { Range } \\
(\text { Mean } \pm S D)\end{array}$ & $\begin{array}{c}3.5-5.5 \\
(4.74 \pm 0.7) \\
\end{array}$ & $\begin{array}{c}1.5-2.5 \\
(1.93 \pm 0.32) \\
\end{array}$ & NA & 0.001 \\
\hline \multirow[b]{2}{*}{$\mathrm{RF}$ IU/ml } & (positive/negative) & $21 / 4$ & $12 / 13$ & $0 / 25$ & 0.0001 \\
\hline & $\begin{array}{l}\text { Range } \\
(\text { Mean } \pm S D)\end{array}$ & $\begin{array}{c}48-256 \\
(131.7 \pm 81.9) \\
\end{array}$ & $\begin{array}{c}24-41 \\
(35.5 \pm 6.89) \\
\end{array}$ & NA & 0.001 \\
\hline Anti CCP U/ml & $\begin{array}{l}\text { Range } \\
(\text { Mean } \pm S D)\end{array}$ & $\begin{array}{c}61-94 \\
(75.73 \pm 9.3) \\
\end{array}$ & $\begin{array}{c}24-41 \\
(35.5 \pm 6.89)\end{array}$ & NA & 0.001 \\
\hline Larsen score & $\begin{array}{l}\text { Range } \\
(\text { Mean } \pm S D)\end{array}$ & $\begin{array}{c}0-16 \\
(3.84 \pm 4.3)\end{array}$ & $\begin{array}{c}0-10 \\
(3.8 \pm 3.03)\end{array}$ & NA & \\
\hline
\end{tabular}


Table 1. Followed.

\begin{tabular}{|c|c|c|c|c|c|}
\hline & & $\begin{array}{c}\text { Group I } \\
\text { Active RA (25) } \\
\end{array}$ & $\begin{array}{c}\text { Group II } \\
\text { Inactive RA (25) } \\
\end{array}$ & $\begin{array}{c}\text { Group III } \\
\text { NC group(25) } \\
\end{array}$ & P-value \\
\hline $\begin{array}{l}\begin{array}{l}\text { ESR } 1^{\text {st }} \text { hour } \\
(\mathrm{mm})\end{array} \\
\end{array}$ & $\begin{array}{l}\text { Range } \\
(\text { Mean } \pm S D)\end{array}$ & $\begin{array}{c}55-120 \\
(83.76 \pm 14.7) \\
\end{array}$ & $\begin{array}{c}14-22 \\
(18.2 \pm 2.84) \\
\end{array}$ & $\begin{array}{c}10-15 \\
(12 \pm 2.5) \\
\end{array}$ & 0.001 \\
\hline \multirow[b]{2}{*}{$\mathrm{CRP} \mathrm{mg} / \mathrm{ml}$} & (positive/negative) & $18 / 7$ & $3 / 22$ & $0 / 25$ & 0.0001 \\
\hline & $\begin{array}{l}\text { Range } \\
(\text { Mean } \pm S D)\end{array}$ & $\begin{array}{c}12-96 \\
(31.16 \pm 15.55) \\
\end{array}$ & $\begin{array}{c}6-12 \\
(8.05 \pm 2.14) \\
\end{array}$ & NA & 0.021 \\
\hline BMI Kg/m² & $\begin{array}{l}\text { Range } \\
(\text { Mean } \pm S D)\end{array}$ & $\begin{array}{c}18.5- \\
24.9(20.7 \pm 1.8) \\
\end{array}$ & $\begin{array}{c}18.5-24.9 \\
(20.9 \pm 1.7) \\
\end{array}$ & $\begin{array}{c}18.5-24.9 \\
(21.4 \pm 1.9) \\
\end{array}$ & 0.48 \\
\hline FBG mg/dl & $\begin{array}{l}\text { Range } \\
(\text { Mean } \pm \text { SD) }\end{array}$ & $\begin{array}{c}70-90 \\
(81.96 \pm-5.8)\end{array}$ & $\begin{array}{c}64-90 \\
(81.5 \pm-5.7)\end{array}$ & $\begin{array}{c}72-90 \\
(80.7 \pm 4.95)\end{array}$ & 0.72 \\
\hline $\mathrm{TC} \mathrm{mg} / \mathrm{dl}$ & $\begin{array}{l}\text { Range } \\
(\text { Mean } \pm \text { SD) }\end{array}$ & $\begin{array}{c}205-269 \\
(228.1 \pm 16.6) \\
\end{array}$ & $\begin{array}{c}105-202 \\
(169.9 \pm 26.8)\end{array}$ & $\begin{array}{c}111-179 \\
(151.3 \pm 19.2)\end{array}$ & 0.001 \\
\hline $\mathrm{TG} \mathrm{mg} / \mathrm{dl}$ & $\begin{array}{l}\text { Range } \\
(\text { Mean } \pm \text { SD) }\end{array}$ & $\begin{array}{c}171-248 \\
(202.6 \pm 24.6)\end{array}$ & $\begin{array}{c}84-169 \\
(134.5 \pm 21.7) \\
\end{array}$ & $\begin{array}{c}52-151 \\
(101.1 \pm 25.2) \\
\end{array}$ & 0.001 \\
\hline LDL mg/dl & $\begin{array}{l}\text { Range } \\
(\text { Mean } \pm \text { SD) }\end{array}$ & $\begin{array}{c}168-272 \\
(210.4 \pm 33.6)\end{array}$ & $\begin{array}{c}81-167 \\
(138.1 \pm 20.1)\end{array}$ & $\begin{array}{c}77-234 \\
(134 \pm 37.5)\end{array}$ & 0.001 \\
\hline
\end{tabular}

Non applicable (NA)

Table 2. Treatments received by RA patients.

\begin{tabular}{lcc}
\hline \multicolumn{1}{c}{ Treatment } & $\begin{array}{c}\text { Group I } \\
\text { N(\%) }\end{array}$ & $\begin{array}{c}\text { Group II } \\
\text { N(\%) }\end{array}$ \\
\hline Methotrexate & $25(100 \%)$ & $15(60 \%)$ \\
Leflunomide & $10(40 \%)$ & $16(64 \%)$ \\
Sulfasalazine & $5(20 \%)$ & $3(12 \%)$ \\
Hydroxychloroquine & $20(80 \%)$ & $10(40 \%)$ \\
Biologics & $2(8 \%)$ & 0 \\
\hline
\end{tabular}

Table 3. Serum resistin level in studied groups.

\begin{tabular}{|c|c|c|c|}
\hline \multirow{2}{*}{ Groups } & \multicolumn{2}{|c|}{ Resistin ng/ml } & \multirow{2}{*}{$\begin{array}{l}\text { ANOVA } \\
\text { P-value }\end{array}$} \\
\hline & Range & mean \pm SD & \\
\hline Group I & $68.5-82.1$ & $74.22 \pm 5.04$ & \\
\hline Group II & $3.6-39.3$ & $15.36 \pm 11.06$ & 0.001 \\
\hline Group III & $2.4-31.4$ & $7.54 \pm 5.45$ & \\
\hline
\end{tabular}

Tukey's test

Group I \& Group II

$$
\mathrm{P}=0.001
$$

Group I \& Group III

$\mathrm{P}=0.001$
Group II \& Group III

$\mathrm{P}=0.002$ 
Table 4. Correlation of resistin with clinical, metabolic and inflammatory markers in RA patients.

\begin{tabular}{lcc}
\hline & \multicolumn{1}{c}{$\begin{array}{c}\text { RA patients } \\
\text { Group I + Group II }\end{array}$} & Resistin \\
\cline { 2 - 3 } & $\mathbf{r}$ & P \\
\hline Duration of disease in years & 0.031 & 0.832 \\
DAS 28 & 0.664 & $<0.001$ \\
Larsen score & 0.08 & 0.74 \\
ESR & 0.918 & $<0.001$ \\
CRP & 0.498 & $<0.001$ \\
RF & 0.666 & $<0.001$ \\
Anti CCP & 0.847 & $<0.001$ \\
FBG & 0.082 & 0.57 \\
TC & 0.748 & $<0.001$ \\
TG & 0.798 & $<0.001$ \\
LDL & 0.77 & $<0.001$ \\
\hline
\end{tabular}

\section{DIsCussion}

Rheumatoid arthritis (RA) is a chronic autoimmune inflammatory condition ${ }^{11}$. Resistin, an adipocyte-secreted hormone, has gained attention for its involvement in insulin resistance in obesity and diabetes mellitus. Several groups have reported a close relationship between resistin and inflammation. Resistin increases the production of pro-inflammatory cytokines TNF- $\alpha$ and interleukin (IL)-12, both of which are important for $\mathrm{T}$ cell development ${ }^{12}$.

The aim of the present study was the assessment of serum resistin in lean rheumatoid arthritis patients and whether it correlates with disease activity and radiological joint damage or not.

Since plasma resistin levels in humans, has been found to correlate with determinants of the metabolic syndrome and with obesity ${ }^{13-14}$. We excluded patients with $\mathrm{BMI} \geq 25$ and patients with DM from our study.

In the present work we found that serum resistin was significantly higher in both active and inactive RA when compared to controls $(\mathrm{P}=0.001,0.002)$ respectively. Also it was significantly increased in active RA when compared to inactive RA ( $\mathrm{P}=0.001)$.

In agreement with our work, Kassem et al. ${ }^{15}$ documented a significant increase in serum resistin in RA patients when compared to controls $(\mathrm{P}<0.001)$. Canoru et al. ${ }^{16}$ as well reported that patients with RA showed considerably higher plasma levels of resistin than healthy controls $(\mathrm{P}<0.0001)$. Migita et al. ${ }^{17}$ reported serum resistin levels to be significantly higher in RA patients compared to the control subjects $(\mathrm{P}=0.0005)$ which was consistent with our results.
In contrary to our results, Hammad et al. ${ }^{18}$ reported that there were insignificant differences of resistin level in RA patients and controls $(\mathrm{P}>0.05)$.

We noticed a significant positive correlation between serum resistin level and the following: DAS 28, ESR, CRP, RF, Anti CCP, TC, TG, LDL with ( $\mathrm{P}=0.001)$ for all. While there were insignificant positive correlations with the disease duration, BMI, FBG, and Larsen score ( $\mathrm{p}=0.832,0.72,0.57,0.74)$ respectively.

Similar results were reported by Forsblad et al. ${ }^{19}$, who documented that resistin was positively associated CRP $(\mathrm{P}=0.008)$. In consistence with our results, Migita et al. ${ }^{17}$, Senolt et al. ${ }^{20}$ and Kassem et al. ${ }^{15}$ found statistically significant correlations between resistin levels in the serum of RA patients and ESR and CRP. Also Gonzalez et al. $^{21}$, confirmed the association between serum resistin and laboratory markers of inflammation, particularly CRP.

Yoshino et al. ${ }^{22}$ as well reported that serum resistin was positively associated with CRP in patients with RA, suggesting that it may act as proinflammatory cytokine in this disease. Senolt et al. ${ }^{20}$ as well, found a positive correlation between serum resistin levels and disease activity based on DAS 28 in patients with RA. All the previous studies support the inflammatory role of resistin.

On the contrary to our results, the studies conducted by Forsblad et al. ${ }^{19}$, Kassem et al. ${ }^{15}$ and Rho et $\mathrm{al}^{23}$ found a significant positive correlation between serum resistin levels and Larsen score for radiological joint damage in RA patients $(\mathrm{p}<0.05)$. While Canoru et al. ${ }^{16}$ recorded that there was no significant correlation between resistin and ESR, and CRP. On the other hand, Senolt et al. ${ }^{20}$ found a positive association between serum resistin level and 
disease duration in patients with RA, and reported that resistin was associated with higher Larsen scores despite the absence of higher serum concentrations in patients with RA than in controls.

The results obtained by Kang et al. ${ }^{24}$ were partially in accordance with ours, as they documented that serum resistin was associated with $\operatorname{ESR}(\mathrm{P}=0.001)$, $\mathrm{CRP}(\mathrm{P}-0.004)$ and increased disease duration $(\mathrm{P}=0.014)$, while it didn't correlate with DAS 28 or TG. While Rho et al. ${ }^{23}$ reported that the concentrations of resistin did not differ significantly among patients with seropositive and seronegative RA. They also reported that disease duration, DAS 28, Larsen score, and CRP were not correlated with resistin.

The contradictory results found in other studies may be related to the different co-morbidities that may be present in obese patients and may affect resistin level as diabetes, insulin resistance, and atherosclerosis.

Our study was limited by a small number of subjects and absence of synovial fluid analysis, as resistin is present in rheumatoid synovial tissue and synovial fluid ${ }^{25}$. In the future, other studies including more RA patients might be needed to precise the role of resistin in RA subjects.

\section{Conclusion}

The results of this study provide an evidence for the association between serum resistin level and disease activity, suggesting that it may be useful in evaluating RA disease activity, and serve as a future therapeutic target.

\section{REFERENGES}

1. ED. Rheumatoid arthritis: pathophysiology and implications for therapy. N Engl J Med1990; 322:1277-89.

2. Fujita Y, Murakami M, Ogawa Y, Masuzaki H, Tanaka M, Ozaki S, et al. Leptin inhibits stress induced apoptosis of $\mathrm{T}$ lymphocytes. Clin Exp Immunol 2002; 128:21-6.

3. Reilly MP, Lehrke M, Wolfe ML, Rohatgi A, Lazar MA, Rader DJ. Resistin is an inflammatory marker of atherosclerosis in humans. Circulation 2005; 111:932-9.

4. Karmiris K, Koutroubakis IE, Xidakis C, et al. Circulating levels of leptin, adiponectin, resistin, and ghrelin in inflammatory bowel disease. Inflamm Bowel Dis 2006; 12:100-105.

5. Patel L, Buckels AC, Kinghorn IJ, et al. Resistin is expressed in human macrophages and directly regulated by PPAR gamma activators. Biochem Biophys Res Commun 2003; 300:472-476.
6. Bokarewa M, Nagaev I, Dahlberg L, et al. Resistin, an adipokine with potent proinflammatory properties. J Immunol 2005; 174:5789-5795.

7. Arnett FC, Edworthy SM, Bloch DA, et al. The American Rheumatism Association 1987 revised criteria for the classification of rheumatoid arthritis.Arthritis Rheum 1988;31:315-24.

8. Prevoo ML, van't Hof MA, Kuper HH, van Leeuwen MA, van de Putte LB, van Riel PL. Modified disease activity scores that include twenty-eight-joint counts. Development and validation in a prospective longitudinal study of patients with rheumatoid arthritis. Arthritis Rheum $1995 ; 38: 44-8$.

9. Kaarela K, Kautiainen H. Continuous progression of radiological destruction in seropositive rheumatoid arthritis. J Rheumatol 1997; 24:1285-7.

10. Larsen A. How to apply Larsen score in evaluating radiographs of rheumatoid arthritis in long-term studies. J Rheumatol 1995;22: 1974-5.

11. Koerner A, Kratzsch J, Kiess W Adipocytokines: leptin-the classical, resistin-the controversical, adiponectin-the promising, and more to come. Best Pract Res Clin Endocrinol Metab 2005; 19: 525546.

12. Son YM, Ahn SM, Jang MS, et al. Immunomodulatory effect of resistin in human dendritic cells stimulated with lipoteichoic acid from Staphylococcus aureus. Biochem Biophys Res Commun 2008; 376:599-604.

13. Norata GD, Ongari M, Garlaschelli K, Raselli S, Grigore L, Catapano AL. Plasma resistin levels correlate with determinants of the metabolic syndrome. Eur J Endocrinol 2007; 156:279-84.

14. Degawa-Yamauchi M, Bovenkerk JE, Juliar BE et al. Serum resistin (FIZZ3) protein is increased in obese humans. J Clin Endocrinol Metab 2003; 88:5452-5.

15. Kassem E, Mahmoud L, Salah W. Study of resistin and YKL-40 in rheumatoid arthritis. Journal of American Science 2010;6( 10):31-35.

16. Canoru N, Kale E, Turhanoğlu A, et al. Plasma resistin and leptin levels in overweight and lean patients with rheumatoid arthritis Turk J Med Sci 2009; 39 (3): 447-451

17. Migita K, Miyashita T, Maeda Y, et al. Toll-like receptor expression in lupus peripheral blood mononuclear cells. J Rheumatol 2007; 34:493.

18. Hammad M, Nasef S, Elsammak M et al. Resistin, an adipokine, its relation to inflammation in Systemic Lupus Erythematosus and Rheumatoid Arthritis. Middle East Journal Of Internal Medicine 2014; 7 (3) :3-9.

19. Forsblad d'Elia H, Pullerits R, Carlsten $\mathrm{H}$ et al. Resistin in serum is associated with higher levels of IL-1Ra in post-menopausal women with rheumatoid arthritis. Rheumatology 2008;47:10821087. 
20. Senolt L, Housa D, Vernerova Z, et al. Resistin in rheumatoid arthritis synovial tissue, synovial fluid and serum," Annals of the Rheumatic Diseases 2007 ; vol. 66, no. 4, pp. 458-463.

21. Gonzalez A, Garcia T, Gonzalez C et al. Anti-TNFalpha therapy modulates resistin in patients with rheumatoid arthritis. Clin Exp Rheumatol 2008; 26(2):311-316

22. Yoshino T, Kusunoki N, Taneko $\mathrm{K}$ et al. Elevated serum levels of resistin, leptin, and adiponectin are associated with $\mathrm{C}$-reactive protein and also other clinical conditions in rheumatoid arthritis. Intern Med. 2011; 50: 269-275.
23. Rho Y, Solus J, Sokka T et al: Adipocytokines Are Associated With Radiographic Joint Damage in Rheumatoid Arthritis. Arthritis \& rheumatism 2009; 60, (7): 1906-1914.

24. Kang Y, Park H , Kang $M$ et al. Adipokines, inflammation, insulin resistance, and carotid atherosclerosis in patients with rheumatoid arthritis Arthritis Research \& Therapy 2013; 15:R194.

25. Schaffler A, Ehling A, Neumann E, et al Adipocytokines in synovial fluid. JAMA 2003; 290:1709-10. 